\title{
GENETICS OF PSORIASIS - SHORT RESUME
}

\author{
Valentova V. ${ }^{1}$, Galajda P. ${ }^{2}$, Pec M. ${ }^{1}$, Mokan M. ${ }^{2}$, Pec J. ${ }^{3}$
}

${ }^{1}$ Department of Medical Biology, Jessenius Faculty of Medicine, Comenius University, Martin, ${ }^{2} \mathrm{Clinic}$ of Internal Medicine I., Jessenius Faculty of Medicine, Comenius University, Martin, ${ }^{3} \mathrm{Clinic}$ of

Dermatovenerology, Jessenius Faculty of Medicine, Comenius University, Martin, Slovak Republic

\begin{abstract}
Psoriasis is a disease with a genetic background (4). Several psoriasis susceptibility loci (PSORS) have been found on various chromosomes: PSORS1 on 6p21.3, PSORS2 on 17q, PSORS3 on 4q, PSORS4 on 1q21, PSORS5 on 3q21, PSORS6 on 19p, PSORS7 on 1p, PSORS8 on 16q, PSORS9 on 4q31, PSORS10 on $18 p 11$, PSORS11 on 5q31-q33 and PSORS12 on 20q13. (27). However, the exact genes and their functions, or their respective malfunctions, in psoriasis and arthritis have not been unambiguously identified. Recently, it has been argued that PSORS1 may indeed be the HLA-Cw*06 allele encoding the HLA-Cw6 molecule (35).

Psoriasis is a chronic inflammatory disease of skin that also often affects joints and nails. This disorder is characterized by hyperproliferation of keratinocytes, activation of angiogenesis, vasodilatation and mainly by lymphocyte infiltration of dermis and epidermis (45). The process of maturation of keratinocytes is accelerated and thus not quite terminated. Psoriatic lesion appears on skin.

Skin manifestations are typically red bounded areas of different size and shape with characteristic silvery scales (9). Lesions appear mostly on the skin of elbows and knees, scalp including genitals. Individual manifestations differ in size and severity from localized lesions to whole body involvement. Very often psoriasis affects nails of hands and feet. It can also cause inflammatory changes on joints, named as psoriatic arthritis. Similarly to rheumatoid arthritis and sclerosis multiplex, psoriasis is classified as an immune mediated inflammatory disorder. Those disorders are characterized by chronic progression of an inflammatory process and important role of TNF alpha. Because of the role of TNF alpha in pathogenesis, we can use its inhibitors in therapy. It also affects progress of different comorbidities such as diabetes mellitus 2 and cardiovascular problems (21). Patients with psoriasis have often other risk factors for atherosclerosis such as lipid metabolism disorders and overweight (37).
\end{abstract}

Key words: psoriasis, PSORS, HLA-Cw6

\section{INTRODUCTION}

Psoriasis is characterized by hyperproliferation and abnormal differentiation of epidermal keratinocytes, by lymphocytary infiltrate composed mainly of T-cells. Other features are change of endothelium, angiogenesis, dilatation and formation of high endothelial venules (HEV) (29).

Exact pathogenesis of this disorder is unknown, but it is supposed that main role plays an immune system $(42,45)$.

Theory that psoriasis is primarily keratinocyte proliferation disorder is based on abnormally fast mitotic activity of keratinocytes. T-cell hypothesis imply an abnormal activation of an acquired immunity. Knowing that TNF alpha therapies are very effective, suggests an important role of innate immunity in pathogenesis (5).

Address for correspondence:

Mgr. Vanda Valentova, Department of Medical Biology, Jessenius Faculty of Medicine, Comenius University Mala Hora Str. 4, 03601 Martin, Slovak Republic, Phone: +4210434131425, E-mail: valentova@jfmed.uniba.sk 


\section{SHORT REVIEW OF LOCI AND CANDIDATE GENES}

In the early 1970s psoriasis was placed into associations with the HLA complex on chromosome 6p. Russell et al. in 1972 first reported association with allele HLA-B13. After that, were identified strong associations with other two alleles, Cw6 and DR7 (22, 49). These two alleles were estimated to be relative risk factors for the disease.

There are two types of psoriasis (23):

- a familial, early age of onset form $(<40$ years $)$

- associated with HLA-Cw6, DR7, B13 and B57

- a non-familial, later age at onset form

- associated with HLA-Cw2 and B27

Psoriasis is a disorder with genetic background and a multifactorial type of heredity. The hypothesis of genetic background is also supported by familial incidence. Chance that a child of nonpsoriatic parents will develop psoriasis is $12 \%$, if there is a one parent with psoriasis the risk is higher $10-20 \%$ and in a case that both parents are having psoriasis it can be up to $50 \%$ risk. In identical twins the risk that they will develop disease is about $90 \%$, in nonidentical twins its only $18 \%$ (9). This difference shows a multifactorial type of inheritance and interaction between genetic predisposition and environmental influence $(8,14)$. Based on the study of Bowcock and Barker from 2003 plaque psoriasis can be in small group of patients inherited as an autosomal dominant trait with high penetrance (6).

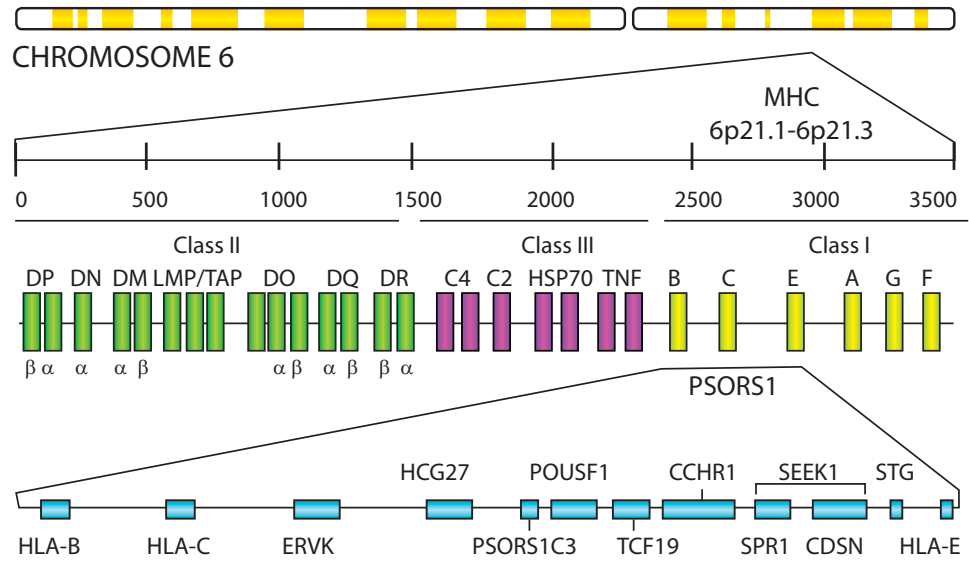

Fig. 1: Localization of locus PSORS1 in MHC locus, and candidate genes in PSORS1 locus (28).

Recently the results of multiple genetic case-control studies have begun to appear providing convincing statistical evidence for six loci (IL12B, IL13, IL23R, STAT2/IL23A, TNFAIP3, and TNIP1) for psoriasis (32).

In these days 10 loci are known named as PSORS1-10 (psoriasis susceptibility 1-9) and one for psoriatic arthritis, PSORAS1 $(1 ; 13)$. Exact genes and their function are not yet identified (28). There is a possibility, of location PSPRS 1 in allele of HLA-Cw6 coding HLA-Cw6 molecule $(15,36)$.

Using high-density cDNA microarray to identify psoriatic transcriptome and to set down gene expression in psoriatic lesions elevated expression of different molecules was found. Increased expression of certain mRNA associated with the epidermal differentiation complex and hyperproliferation-associated molecules (keratins KRT6A a KRT16) supports hypothesis that psoriasis is keratinocyte disorder, characteristic with their increased proliferation and abnormal differentiation $(7,39,41,57)$. 
It is possible that malfunction of $\mathrm{CD} 4+\mathrm{CD} 25+$ regulatory lymphocytes can be partially based on abnormal hematopoietic cells and with genetic background (55).

Table 1: PSORS loci (10)

\begin{tabular}{|l|l|l|}
\hline Locus name & Chromosomal location & Reference \\
\hline PSORS 1 & $6 \mathrm{p} 21.3$ & Zhang et al., 2002 \\
\hline PSORS 2 & $17 \mathrm{q} 24-25$ & Samuelsson et al., 1999 \\
\hline PSORS 3 & $4 \mathrm{q} 34$ & Samuelsson et al., 1999 \\
\hline PSORS 4 & $1 \mathrm{q} 21$ & Capon et al., 1999 \\
\hline PSORS 5 & $3 \mathrm{q} 21$ & Enlund et al., 1999 \\
\hline PSORS 6 & $19 \mathrm{p} 13-\mathrm{q} 13$ & Lee et al., 2000 \\
\hline PSORS 7 & $1 \mathrm{p} 35-\mathrm{p} 34$ & Veal et al., 2001 \\
\hline PSORS 8 & $16 \mathrm{q}$ & Karason et al., 2003 \\
\hline PSORS 9 & $4 \mathrm{q} 31$ & Zhang et al., 2002 \\
\hline PSORS 10 & $18 \mathrm{p} 11.23$ & Asumalahlati et al., 2002 \\
\hline PSORS 11 & $5 \mathrm{q} 31-\mathrm{q} 33$ & www.ncbi.nlm.nih.gov/omim \\
\hline PSORS 12 & $20 \mathrm{q} 13$ & www.ncbi.nlm.nih.gov/omim \\
\hline
\end{tabular}

\section{PSORS1}

The most studied locus is PSORS1 mapped to MHC complex on chromosome 6. This region contains genes coding proteins of immunological pathways and is strongly associated with genes of lymphocyte antigens also situated in this area $(1,11)$. Main marker of this area is HLA-Cw6 (48). This allele is most frequently mapped in population with early onset psoriasis (36).

\section{Human leukocyte antigen}

Psoriasis has signs of an autoimmune disease and there is no surprise that there was found association with certain HLA alleles. Also a role for CD8+ cells is favoured by the observed linkage of psoriasis to certain MHC I alleles, especially HLA Cw6 (20).

Only about $10 \%$ of HLA-Cw6-positive individuals develop psoriasis, suggesting a major role for additional genes and/or environmental triggers (30).

The observation that a large, multiply affected family demonstrated linkage of psoriasis susceptibility to $17 \mathrm{q} 25$ (50) and not to HLA suggests that other genes can confer susceptibility. In a study of 23 multiply affected families was observed that $25 \%$ are HLA-Cw6 positive. In one family, all three affected members are HLA-B27 $(4,33,35)$.

\section{PSORS2}

Locus is situated near telomeres of chromosome 17q (50). Exact localization of risk allele is not known. In this area at least two candidate genes are expected, but last large study eliminated them both (47). 


\section{PSOORS3}

Localized is on chromosome 4 , in position 4q34. A relation with early onset psoriasis was found in this area (17). Responsible gene is mapped about 50kb from former marker of PSORS3 locus. The newest localization is for PSORS9 locus, mapped closer to centromere $(4 \mathrm{q} 31)$ in PSORS3 area $(25,56)$. In this region are situated different genes coding immunologically important proteins, including IL-15 gene (53).

\section{PSORS4}

Locus PSORS4 mapped to 1q21 of chromosome 4, in area of Epidermal differentiation complex. This region involves 13 genes coding S100 calcium binding proteins. Some of them, S100A7, S100A8 a S100A9 are known to be increased in keratinocytes of psoriatic patients (44). S100 proteins are responsible for chemotaxis of leukocytes.

\section{PSORS5}

Localized to $3 q 21$ but his exact position is need to be confirmed by more studies (43).

\section{PSORS6}

Mapped to 19p13 and his position is also not exact. In this area is mapped also gene JUNB, which product is member of AP-1 family of transcriptional factors, that control differentiation of keratinocytes (54).

\section{PSORS7}

Locus is situated in position 1p. Veal et al. (52) referred to fact that gene EPS15 coding intracellular substrate for EGF receptors, highly expressed in psoriatic skin, and is mapped to critical region in position of $1 \mathrm{p}$.

\section{PSORS8}

This locus is mapped to 16q. Nair et al. (35) referred that PSORS8 area is overlapping with susceptibility locus for Crohn disease. They found that this locus contains NOD2/ CARD15 gene. They also found that psoriasis is more often in patients with Crohn disease, in comparison to control group. It shows a possibility that in this region is localized an immunomodulatory locus able to affect both diseases.

\section{PSORS9}

Locus is mapped to $4 \mathrm{q}$ position.

\section{IL-10}

IL-10 plays an important role in the pathophysiology of psoriasis. This disease is characterized by a relative IL-10 deficiency that can in part explain the predominance of a Th1 response. The IL-10 promoter region is very polymorphic and controls transcription of the IL-10 gene $(3,24)$.

While the concept of an allele that makes an individual susceptible to a disease is easily understood, the concept of a protective allele of a predisposing gene is rather new in the genetics of psoriasis. 
Table 3: Frequencies and allele sizes of interleukin (IL)-10.G (a) - Allele nomenclature at the Genome Data Base (http://www.gdb.org) (24).

\begin{tabular}{|l|l|l|}
\hline Size (bp) & Frequency & GDB $^{\mathbf{a}}$ \\
\hline 132 & 0.022 & Allele 12 \\
\hline 134 & 0.034 & Allele 11 \\
\hline 136 & 0.399 & Allele 10 \\
\hline 138 & 0.075 & Allele 9 \\
\hline 140 & 0.079 & Allele 8 \\
\hline 142 & 0.052 & Allele 7 \\
\hline 144 & 0.240 & Allele 6 \\
\hline 146 & 0.086 & Allele 5 \\
\hline 148 & 0.011 & Allele 4 \\
\hline
\end{tabular}

Other study analyzed the highly polymorphic IL10.G microsatellite to determine if IL10 has a role in psoriasis susceptibility. Findings showed a possible role of IL-10 promoter polymorphism in disease susceptibility and the G13 allele at the IL10.G locus was found to be associated with psoriasis (3).

Other allele, allele 3 (IL10.G9) apparently has a small protective effect and is the most frequent allele of this multiallelic polymorphism allele 3 (IL10.G9) was present in $80 \%$ of the families (24).

The effect of the IL10.G9 promoter polymorphism observed by Hensen et al. is small compared with the effect of the PSORS1 marker. They also observed a small effect for allele 8 (IL10.14). This allele was present in only $28 \%$ of the families (24).

\section{SPP2 (Secreted phosphoprotein 2)}

Bandshift analysis showed that SPP2 is $\mathrm{NF}-\mathrm{kB}$ dependent gene. High positive regulation of $\mathrm{NF}-\alpha \mathrm{B}$ dependent gene was detected in samples from affected skin of psoriatic patients (34). NF- $x$ B induces expression of VCAM- 1 trough homocysteine. Protein vCAM1 enables adhesion of lymphocytes, monocytes, eosinophiles and basophiles to endothelium of blood vessels. It also has a function in signal transport between leukocytes and endothelial cell.

\section{VDR}

D vitamin receptor is one of the candidate genes in psoriasis. It has immunosuppressive effects and is involved in an antiproliferation and prodifferentiaton cascades in keratinocytes (18). Neutrophils are expressing VDR. Polymorphism in A allele, A-1012G, is linked to negative regulation of TH1 response trough Trans-acting T-cell-specific transcription factor GATA-3. Alleles $\mathrm{F}$ and $\mathrm{T}$ of Fok 1 and Taq1 genes are involved in increased activity of VDR. A-1012G, Fok1 and Taq1 VDR gene polymorphism is linked to with answer to calcipotriol (synthetic vitamin D3). A-1012G and Fok1 have relationship with susceptibility to non-familial psoriasis (18). 


\section{ADAM33 and other genes}

Polymorphism in locus ADAM33, first gene identified in asthma, is in these days given to relation with psoriasis (46).

Li et al. have tested 15 SNPs form 7 expected psoriatic risk genes: rs597980 in allele ADAM33, rs6908425 in CDKAL1 and rs3789604 in PTPN22. Results have shown as significant for the same alleles as in previous studies. This data show, that ADAM33, CDKAL1, and PTPN22 are risk genes for psoriasis (32).

Study of Oudota et al. in year 2009, confirmed linkage of other six candidate genes to susceptibility to psoriasis: SCL12A8, belongs to group of free transposing genes; FLG and TGM5, involved in epidermal differentiation; CARD15 and CYLD, that modulate transcriptional factor $\mathrm{NF}-\kappa \mathrm{B}$ and IL1RN, coding antagonist receptor of IL-1. It was proved that an association exists between main risk allele HLA-Cw6 and CARD15, CYLD and TMG5 alleles. Together these results show that etiology of psoriasis and other disorders is cooperation of different genetic factors (40).

One region is within the MHC complex on 6p21.3 (51) and includes the non-HLA geneencoding corneodesmosin (CD) - a protein with homology to keratin-10 (2). The other region includes a cluster of genes on chromosome 1q21 $(19,38)$. Potential candidate genes encode markers of epidermal differentiation such as corneodesmosin, psoriasin, and CD1d, to name a few (19).

\section{IL-20R}

Complex of IL-20 receptor is composed from two chains IL20RA and IL20RB. Its ligands are three members from IL-19 subfamily, IL-19, IL-20 and IL-24. These cytokines are important for manifestation of psoriatic lesions and recently was described also a relation between IL20 gene polymorphism and psoriasis. In last studies the hypothesis is tested, that genetic variants of IL-20-RI influence susceptibility to psoriasis. To these days there isn't proved relationship between SNP in that gene and psoriasis. SNPs in two risk haplotypes influence two transcriptional factors leading to differentiation of immune cells. Other studies are necessary to confirm genetic association of IL-20-RA haplotypes with psoriasis (27).

\section{Conclusion}

In the last few years, molecular genetics analyses have permitted novel insights into psoriasis, a disease characterized by uncontrolled proliferation of keratinocytes and recruitment of $\mathrm{T}$ cells into the skin. HLA studies revealed an association with certain alleles, notably HLA-Cw6. Despite this HLA component, psoriasis in some families is inherited as an autosomal dominant trait with high penetrance.

Significant progress has been made in the understanding of the genetic, immune and pathogenetic aspects of psoriasis.

Understanding the genetics of psoriasis, and why some people are affected and others are not could lead to more effective treatments. They could work blocking the action of concrete genes, changing their behaviour or by replacing mutated genes with healthy ones via gene therapy. 


\section{REFERENCES}

1. Asumalahti K, Veal C, Laitinen T, Suomela S, Allen M, Elomaa O, Moser M, De Cid R, Ripatti S, Vorechovsky I, Marcusson JA, Nakagawa H, Lazaro C, Estivill X, Capon F, Novelli G, Saarialho-Kere U, Barker J, Trembath R, Kere J. Coding haplotype analysis supports HCR as the putative susceptibility gene for psoriasis at the MHC PSORS1 locus. Hum Mol Gene 2002; 11:589-597

2. Allen MH, Veal C, Faassen A, Powis SH, Vaughan RW, Trembath RC, Barker JN. A non-HLA gene within the MHC in psoriasis. Lancet 1999; 353:1589-90

3. Asadullah K, Eskdale J, Wiese A, Gallagher G, Friedrich M, Sterry W. Interleukin-10 promoter polymorphism in psoriasis. J Invest Dermatol 2001; 116:975-978

4. Bhalerao J, Bowcock AM. The genetics of psoriasis: a complex disorder of the skin and immune system. Human molecular genetics 1998; 7:1537-45

5. Bos JD, De Rie MA, Teunissen MB, Piskin G. Psoriasis: dysregulation of innate immunity. Br J Dermatol. 2005; 152:1098-107

6. Bowcock AM, Barker JN. Genetics of psoriasis: the potential impact on new therapies. J Am Acad Dermatol 2003; 49:51-56

7. Bowcock AM, Shannon W, Du F, Duncan J, Cao K, Aftergut K, Catier J, Fernandez-Vina MA, Menter A. Insights into psoriasis and other inflammatory diseases from large-scale gene expression studies. Hum Mol Genet 2001; 10:1793-805

8. Brandrup F, Holm N, Grunnet N, Henningsen K, Hansen HE. Psoriasis in monozygotic twins: variations in expression in individuals with identical genetic constitution. Acta Dermatol 1982; 62:229-36.

9. Braun-Falco O, Plewig G, Wolff H. Dermatológia a venerológia 1. slov. a čes. vyd. Martin, Vydavatelstvo Osveta 2001; 1475s.

10. Campalani E, Barker JNWN. The Clinical Genetics of Psoriasis. Current Genomics 2005; 6:51-60

11. Capon F, Munro M, Barker J, Trembath R. Searching for the major histocompatibility complex psoriasis susceptibility gene. J Invest Dermatol 2002; 118:745-751

12. Capon F, Novelli G, Semprini S, Clementi M, Nudo M, Vultaggio P, Mazzanti C, Gobello T, Botta A, Fabrizi G, Dallapiccola B. Searching for psoriasis susceptibility genes in Italy: genome scan and evidence for a new locus on chromosome 1. J Invest Dermatol 1999; 112:32-35

13. Cookson WOCM, Bowcock AC, Harper JI, Moffat MF. The immunogenetics of inflammatory skin disease. In: Bos JD editor. Skin immune system (SIS): Cutaneous immunology and clinical immunodermatology. 3rd ed. Boca Raton (FL):CRC Press 2005; pp 55-73

14. Duffy DL, Spelman LS, Martin LG. Psoriasis in Australian twins. J Am Acad Dermatol 1993; 29:428-434

15. Elder JT. PSORS1: linking genetics and immunology. J Invest Dermatol 2006; 126:1250-6

16. Enlund F, Samuelsson L, Enerback C, Inerot A, Wahlstrom J, Yhr M, Torinsson A, Riley J, Swanbeck G, Martinsson T. Psoriasis susceptibility locus in chromosome region 3q21 identified in patients from southwest Sweden. Eur J Hum Genet 1999; 7:783-790

17. Foerster J, Nolte I, Schweiger S, Ehlert C, Bruinenberg M, Spaar K, van der Steege G, Mulder M, Kalscheuer V, Moser B, Kijas Z, Seeman P, Ständer M, Sterry W, te Meerman G. Evaluation of the IRF-2 gene as a candidate for PSORS3. J Invest Dermatol 2004; 122:61-4

18. Halsall JA, Osborne JE, Pringle JH, Hutchinson PE. Vitamin D receptor gene polymorphisms, particularly the novel A-1012G promoter polymorphism, are associated with vitamin D3 responsiveness and nonfamilial susceptibility in psoriasis. Pharmacogenet Genomics 2005; 15:349-55

19. Hardas BD, Zhao X, Zhang J, Longqing X, Stoll S, Elder JT. Assignment of psoriasin to human chromosomal band 1q21: coordinate overexpression of clustered genes in psoriasis. J Invest Dermatol 1996; 106:753-8

20. Henseler T, Christophers E. Psoriasis of early and late onset: characterization of two types of psoriasis vulgaris. J Am Acad Dermatol 1985; 13:450-456

21. Henseler T, Christophers E. Disease concomitance in psoriasis. J Am Acad Dermatol 1995; 32:982-986

22. Henseler T, Koch F, Westphal E. Presence of HLA- DR7 in type I psoriasis. J Invest Dermatol 1992; 98:607

23. Henseler T. The genetics of psoriasis. J Am Acad Dermatol 1997; 37:S1-S11

24. Hensen P, Asadullah K, Windemuth C, Rüschendorf F, Hüffmeier U, Ständer M, Schmitt-Egenolf M, Wienker TF, Reis A, Traupe H. Interleukin-10 promoter polymorphism IL10.G and familial early onset psoriasis. Br J Dermatol.2003; 149:381-5.

25. Karason A, Gudjonsson JE, Jónsson HH, Hauksson VB, Runarsdottir EH, Stefansson K, Valdimarsson $\mathrm{H}$, Gulcher JR. Genetics of psoriasis in Iceland: evidence for linkage of subphenotypes to distinct loci. J Invest Dermatol 2005; 124:1177-85 
26. Karason A, Gudjonsson JE, Upmanyu R, Antonsdottir AA, Hauksson VB, Runasdottir EH, Jonsson HH, Gudbjartsson DF, Frigge ML, Kong A, Stefansson K, Valdimarsson H,Gulcher JR. A susceptibility gene for psoriatic arthritis maps to chromosome 16q: evidence for imprinting. Am J Hum Genet 2003; 72:125-131

27. Kingo K, Mössner R, Rätsep R, Raud K, Krüger U, Silm H, Vasar E, Reich K, Kõks S. Association analysis of IL20RA and IL2ORB genes in psoriasis. Genes Immun 2008; 9:445-51

28. Krueger JG, Bowcock A. Psoriasis pathophysiology: current concepts of pathogenesis. Ann Rheum Dis 2005; 64:303-6

29. Krueger JG, Ellis CN. Psoriasis-recent advances in understanding its pathogenesis and treatment. J Am Acad Dermatol 2005; 53:94-100

30. Leder RO and Farber EM. The variable incidence of psoriasis in sub-saharan Africa. Int J Dermatol 1997; 36:911-919

31. Lee YA, Ruschendorf F, Windemuth C, Schmitt-Egenolf M, Stadelmann A, Nurnberg G, Stander M, Wienker TF, Reis A, Traupe H. Genomewide scan in German families reveals evidence for a novel psoriasissusceptibility locus on chromosome 19p13. Am J Hum Genet 2000; 67:1020-1024

32. Li Y, Begovich AB. Unraveling the genetics of complex diseases: susceptibility genes for rheumatoid arthritis and psoriasis. Semin Immunol 2009; 21:318-27

33. Marcos CY, Fernandez-Vina MA, Barnes R. et al. HLA-B and HLA-C genes in familial psoriasis vulgaris (PV): evidence for genetic heterogeneity. Hum Immunol 1997; 55:51

34. Mechtcheriakova D, Wlachos A, Sobanov J, Kopp T, Reuschel R, Bornancin F, Cai R, Zemann B, Urtz N, Stingl G, Zlabinger G, WoisetschlĂger M, Baumruker T, Billich A. Sphingosine 1-phosphate phosphatase 2 is induced during inflammatory responses. Cell Signal 2007; 19:748-60

35. Nair RP, Henseler T, Jenisch S, Stuart P, Bichakjian CK, Lenk W, Westphal E, Guo SW, Christophers E, Voorhees JJ, Elder JT. Evidence for two psoriasis susceptibility loci (HLA and 17q) and two novel candidate regions (16q and 20p) by genome-wide scan. Hum Molec Genet 1997; 6:1349-56

36. Nair RP, Stuart PE, Nistor I, Hiremagalore R, Chia NV, Jenisch S, Weichenthal M, Abecasis GR, Lim HW, Christophers E, Voorhees JJ, Elder JT. Sequence and haplotype analysis supports HLA-C as the psoriasis susceptibility 1 gene. Am J Hum Genet 2006; 78:827-51

37. Naldi L, Chatenoud I, Linder D, Belloni FA, Peserico A, Virgili AR, Bruni PL, Ingordo V, Lo Scocco G, Solaroli C, Schena D, Barba A, Di Ladro A, Pezzarossa E, Arcangeli F, Gianni C, Betti R, Carli P, Farris A, Barbino GF, La Vecchia C. Cigarette smoking, body mass index, and stressful life events as risk factors for psoriasis: results from an Italian case control study. J Invest Dermatol 2005; 125:61-67

38. Nickoloff BJ. The immunologic and genetic basis of psoriasis. Arch Dermatol 1999; 135:1104-10

39. Nomura I, Goleva E, Howell MD, Hamid QA, Ong PY, Hall CF, Darst MA, Gao B, Boguniewicz M, Travers JB, Leung DY. Cytokine milieu of atopic dermatitis, as compared to psoriasis, skin prevents induction of innate immune response genes. J Immunol 2003; 171:3262-9

40. Oudot T, Lesueur F, Guedj M, de Cid R, McGinn S, Heath S, Foglio M, Prum B, Lathrop M, Prud'homme JF, Fischer J. An Association Study of 22 Candidate Genes in Psoriasis Families Reveals Shared Genetic Factors with Other Autoimmune and Skin Disorders. J Invest Dermatol 2009; 129:2637-45

41. Quekenborn-Trinquet V, Fogel P, Aldana-Jammayrac O, Ancian P, Demarchez M, Rossio P, Richards HL, Kirby B, Nguyen C, Voegel JJ, Griffiths CE. Gene expression profiles in psoriasis: analysis of impact of body site location and clinical severity. Br J Dermatol 2005; 152:489-504

42. Sabat R, Philipp S, Höflich C, Kreutzer S, Wallace E, Asadullah K, Volk H-D,Sterry W, Wolk K. Immunopathogenesis of psoriasis. Exp Dermatol 2007; 16:779-798

43. Samuelsson L, Enlund F, Torinsson A, Yhr M, Inerot A, Enerback C, Wahlstrom J, Swanbeck G, Martinsson T. A genome-wide search for genes predisposing to familial psoriasis by using a stratification approach. Hum Genet 1999; 105:523-529

44. Semprini S, Capon F, Tacconelli A, Giardina E, Orecchia A, Mingarelli R, Gobello T, Zambruno G, Botta A, Fabrizi G, Novelli G. Evidence for differential S100 gene over-expression in psoriatic patients from genetically heterogeneous pedigrees. Hum Genet 2002; 111:310-3

45. Schön MP, Boehncke WH. Psoriasis. N Engl J Med 2005; 352:1899-912

46. Siroux V, Bouzigon E, Dizier MH, Pin I, Demenais F, Kauffmann F. Replication of association between ADAM33 polymorphisms and psoriasis. PLoS ONE 2008; 3:2448

47. Stuart P, Nair RP, Abecasis GR, Nistor I, Hiremagalore R, Chia NV, Qin ZS, Thompson RA, Jenisch S, Weichenthal M, Janiga J, Lim HW, Christophers E, Voorhees JJ, Elder JT. Analysis of RUNX1 binding site and RAPTOR polymorphism in psoriasis: no evidence for association despite adequate power and evidence for linkage. J Med Genet 2006; 43:12-7 
48. Suomela S, Kainu K, Onkamo P, Tiala I, Himberg J, Koskinen L, Snellman E, Karvonen SL, Karvonen J, Uurasmaa T, Reunala T, Kivikäs K, Jansén CT, Holopainen P, Elomaa O, Kere J, Saarialho-Kere U. Clinical associations of the risk alleles of HLA- Cw6 and CCHCR1*WWCC in psoriasis. Acta Derm Venereol 2007; 87:127-34

49. Tiilikainen A, Lassus A, Karvonen J, Vartiainen P, Julin M. Psoriasis and HLA-Cw6. Br J Dermatol. 1980; 102:179-84

50. Tomfohrde J, Silverman A, Barnes R, Fernandez-Vina MA, Young M, Lory D, Morris L, Wuepper KD, Stastny P, Menter A et al. Gene for familial psoriasis susceptibility mapped to the distal end of human chromosome 17q. Science 1994; 264:1141-5

51. Trembath RC, Lee Clough R, Rosbotham JL, Jones AB, Camp RDR, Frodsham A, Browne J, Barber R, Terwilliger J, Lathrop GM, Barker JNWN. Identification of a major susceptibility locus on chromosome 6p and evidence for further disease loci revealed by a two stage genome-wide search in psoriasis. Hum Mol Genet 1997; 6:813-820

52. Veal CD, Clough RL, Barber RC, Mason S, Tillman D, Ferry B, Jones AB, Ameen M, Balendran N, Powis $\mathrm{SH}$, Burden AD, Barker JNWN, Trembath RC. Identification of a novel psoriasis susceptibility locus at $1 \mathrm{p}$ and evidence of epistasis between PSORS1 and candidate loci. J Med Genet 2001; 38:7-13

53. Villadsen LS, Schuurman J, Beurskens F, Dam TN, Dagnaes-Hansen F, Skov L, Rygaard J, VoorhorstOgink MM, Gerritsen AF, van Dijk MA, Parren PW, Baadsgaard O, van de Winkel JG. Resolution of psoriasis upon blockage of Il-15 biologic activity in a xenograft mouse model. J Clin Invest 2003; 112:1571-80

54. Zenz R, Eferl R, Kenner L, Florin L, Hummerich L, Mehic D, Scheuch H, Angel P, Tschachler E, Wagner EF. Psoriasis-like skin disease and arthritis caused by inducible epidermal deletion of Jun proteins. Nat 2005; 437:369-75

55. Zhang K, Li X, Yin G, Liu Y, Niu X, Hou R. Functional characterization of CD4+CD25+ regulatory T cells differentiated in vitro from bone marrow-derived haematopoietic cells of psoriasis patients with a family history of the disorder. Br J Dermatol 2008; 158:298-305

56. Zhang XJ, He PP, Wang ZX, Zhang J, Li YB, Wang HY, Wei SC, Chen SY, Xu SJ, Jin L, Yang S, Huang W. Evidence for a major psoriasis susceptibility locus at 6p21 (PSORS1) and a novel candidate region at 4q31 by genome-wide scan in Chinese hans. J Invest Dermatol 2002; 119:1361-6

57. Zhou X, Krueger JG, Kao MC, Lee E, Du F, Menter A, Wong WH, Bowcock AM; Novel mechanism of T-cell and dendritic cell activation revealed by profiling of psoriasis on the 63,100-element oligonucleotide array. Physiol Genomics 2003; 13:69-78

Received: December,6,2010

Accepted: January, 7,2011 